\title{
Bread preservation with use of edible packaging
}

\author{
Silva, V.S. ${ }^{a^{*}}$; Fakhouri, F. M. ${ }^{\text {b }}$ Arias, L. V. A. ${ }^{\text {a }}$; Aguiar, R. H.a ; Oliveira, R.A. ${ }^{\text {a }}$ \\ ${ }^{a}$ Faculty of Agricultural Engineering .University of Campinas, Campinas, Brazil. \\ ${ }^{b}$ Faculty of Food Engineering. University of Grande Dourados, Dourados, Brazil.
}

*E-mail of the corresponding author: vinutry@yahoo.com.br

\begin{abstract}
We live in a world that usually use plastic bags either to go shopping or to pack the snack for a short trip. However, packaging makes life easier and serves as protection for products such as food. Bread is a common food product that needs packaging in order to be protected at storage and transportation. Therefore, with aim of reducing petroleum derived packagin $g$ consumption it was developed an edible film from potato starch to packeg bread and some quality characteristics like water content, firmness and weight loss were evaluated, showing that edible film can be used as a packaging
\end{abstract}

Keywords: biopolymers; edible coatings; packaging materials; starch; storage. 


\section{Introduction}

Bread is the product obtained by the cooking dough at pan, showing elastic and homogeneous crumb, fine pores, thin and soft crust, produced from a mixture of flour, water, yeast and salt [n1]. This is a perishable product because of its high water activity so, its marketing period is short.

One of the shelf life limiting factors is the aging that occurs because of regress and favours to increase crumb firmness, giving a sensation of drying product by the ingestion [n2] this added to the necessary of decrease operational costs and expand the market let the bakers to require new technologies and the development of new methods of dough production [n3].

In this manner, the edible film technology has been implemented recently, there are applied indirectly to the product in the way of a thin layer that acts like a modified atmosphere, being a barrier for gas exchanges and loss of water vapor that can improve handling and the visual appearance of the protected food product [n4; n5].

On the other hand, the use of packaging to increase shelf life is not to recently, however several researches have studied the use of non-conventional packaging. Production of edible films from biopolymers is na alternative technology that has been highlighting because of its ability of increase the conservation time and allows higher handling and marketing flexibility of the product [n6]. Films can be obtained by different types of materials, being more used the polysaccharides, proteins and lipids [n5].

Starch is a polysaccharide that besides being the main source of carbohydrates for human nutrition, also has technological relevance for food, pharmaceutical, paper, textile, materials and oil drilling industries. According to the industry it can be used like a thickener, colloidal stabilizer, gelling agent, paste former and adhesive [n7]. Do to the above, its lower cost and high availability [n8], this polysaccharide stood out to be used at the productive chain. Starch can be obtained from plants and depending on each plant the reserves source of energy can be found in higher quantities at different regions of the plant like such as grains, roots, rhizomes, seeds and stems. The main commercial sources of this carbohydrate are corn, potato and cassava [n9].

In productive chain of bread the packaging is the last stage in which special care must be taken to guarantee longer shelf life. Success in Market depends on product intrinsic quality and packaging effectiveness to preserve and keep quality. Convectional procedure to packaging applied in bakery industry use atmospheric air and coverage materials approved for food. Several researches shown the effectiveness of the packing keeping bread quality characteristics, delaying loss of water content and fungi growth [n10, n 11]. 


\section{Materials and Methods}

\subsection{Elaboration of filmogenic solution}

To produce edible coatings was used methodology proposed by Fakhouri [n12]. Macromolecule used was commercial potato starch $(3 \%$ for $100 \mathrm{~mL}$ of distilled water). The starch and water were deposited in glass beakers and homogenized. This solution was brought to the thermostatic bath (Quimis, Q334 M-14, SP, Brazil) heated to $80^{\circ} \mathrm{C}$. After obtaining the filmogenic solution of potato starch the glycerol is added in a gentle manner to avoid blistering in sample. The film-forming solution was dispersed in petri dishes and dried in an air circulating oven $\left(45^{\circ} \mathrm{C}\right)$ for 6 hours. After drying, films were utilization for packing bread in sealing machine, and stored at room temperature by 3 days.

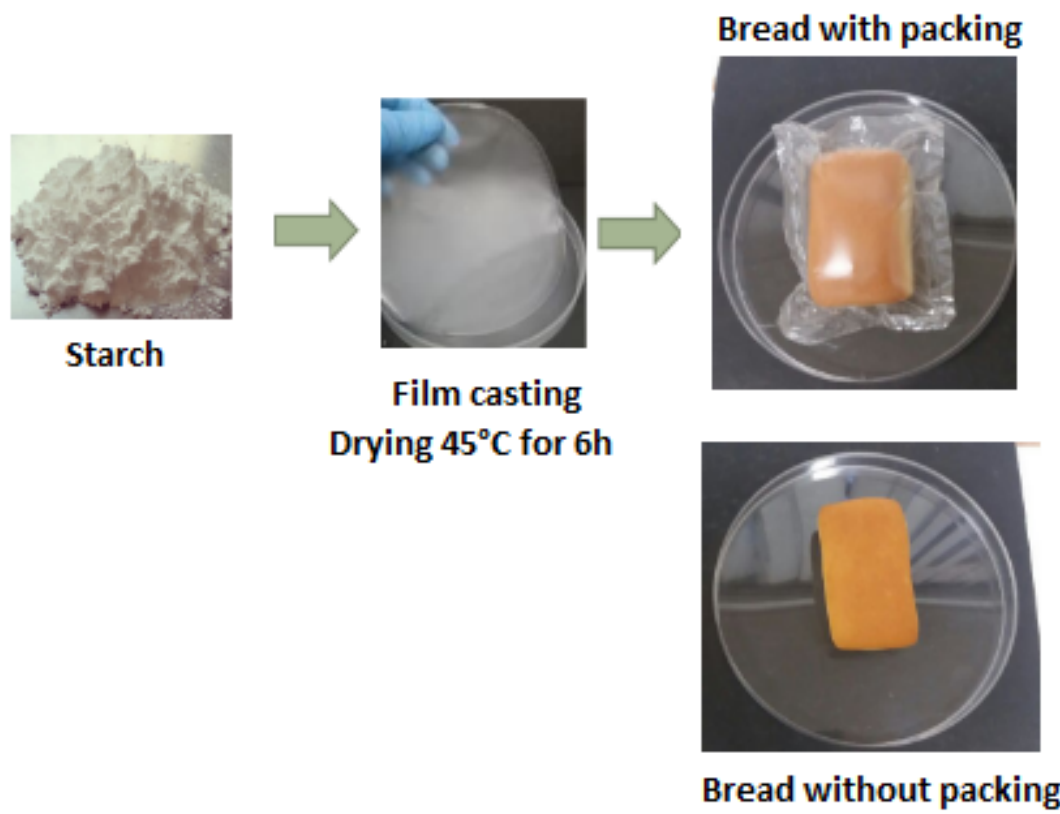

Fig. 1 Production and application of edible packaging of starch potato

It was used small breads (Bisnaguito, Pullman), with weight $\cong 23 \mathrm{~g}$ for unit, obtained local commerce from Campinas city, Brazil. Ingredients contained in small breads: wheat flour fortified with iron and folic acid, sugar, sunflower oil, invert sugar, salt, fatty acid monoglyceride emulsifier, sodium stearoyl-2-lactyl lactate, conservative calcium propionate. 


\subsection{Determination of Water content of bread}

Water content of bread was determined by oven drying at $105{ }^{\circ} \mathrm{C}$ until constant weight. Three slices obtained of bread center $(10 \pm 1 \mathrm{~mm}$ thickness $)$ for each of two repetitions were used.

\subsection{Firmness of bread}

Firmness was measured using the texture analyzer (TA.XT Plus, Stable Micro Systems Co. Ltd., UK) equipped with a $30 \mathrm{~kg}$ load cell and connected with a Warner Bratzler blade set with a speed of $1 \mathrm{~mm} \cdot \mathrm{s}^{-1}$. Three measurements were collected for each treatment and day (0 and 3). Firmness was measured as the maximum shear strength values and expressed as maximum force $(\mathrm{N})$.

\subsection{Weight loss of bread}

Weight loss of bread was determined by weighing the sample in initial day and three days after, in three repetitions were made.

\subsection{Statistical analysis}

Data were submitted analysis of comparison of means by the Tukey test $(\mathrm{p}<0.05)$ through the statistical package Statistics 9.0.

\section{Results and Discussion}

The changes in moisture content, firmness and weight loss of bread are shown at Table 1. The initial crumb moisture content of bread tended to decrease during storage, similar to the observed by Licciardello et al [n13] and others studies [n14, n15] in differently packed durum wheat bread samples. One of the objectives of a packaging system is to reduce water loss, and this can be achieved by materials with suitable barrier to water vapor. The observed results were therefore undesirable to low moisture content value of samples.

Texture is an important characteristic in consumer's perception of food and influences the purchasing decisions. Firming of bread is one of the quality factors in bread ageing and one of the most common parameters used to evaluate staling. A significant increase in firmness was observed for all samples during storage. This result agreed with the water content measures that evidenced likely of starch retrogradation in samples (Table 1), result too observed in other studies [n13, n14, n15].

The products packaged when compared to unpacked showed similar weight loss, however when texture values were observed, sample with packaging showed a lower value than sample without packaging. Indicating that the first one lost less mass than the second, which presented increase of firmness, probable dryness of product. The results showed that 
the packaging did not adversely affect the product, since there was no significant difference between the treatments.

Table 1. Moisture content, firmness and weight loss of bread

\begin{tabular}{|c|c|c|}
\hline Storage time (days) & Bread unp & Bread WP \\
\hline & \multicolumn{2}{|c|}{ Moisture content (\%) } \\
\hline 0 & $26,54 \pm 0,15$ & $26,54 \pm 0,15$ \\
\hline \multirow[t]{2}{*}{3} & $16,94 \pm 0,65^{\mathrm{a}}$ & $16,44 \pm 0,08^{a}$ \\
\hline & \multicolumn{2}{|c|}{ Firmness (N) } \\
\hline 0 & $0,2 \pm 0,06$ & $0,2 \pm 0,06$ \\
\hline \multirow[t]{2}{*}{3} & $1,9 \pm 0,15^{\mathrm{a}}$ & $1,89 \pm 0,37^{\mathrm{a}}$ \\
\hline & \multicolumn{2}{|c|}{ Weight loss $(\mathrm{g})$} \\
\hline 0 & $23,36 \pm 0,41$ & $25,99 \pm 0,57$ \\
\hline 3 & $20,21 \pm 0,04(3,15 \pm 0,45)^{\mathrm{a}}$ & $22,65 \pm 0,31(3,34 \pm 0,48)^{\mathrm{a}}$ \\
\hline
\end{tabular}

unP=unpacked; $\mathrm{WP}=$ with packing

Values are the average \pm standard deviation $(n=3)$. Demonstrated lower case letters that in the same parameter not different from each other $(\mathrm{p}<0.05)$.

At the research led by Cioban et al. [n16] showed that the signs of bread degradation begin to appear after the third day in agreement with what was shown in this work, the smooth and rigid crust becomes wrinkled, elastic and soft, compressing core turns into brittles and becomes less compressing and rigid when stored.

\section{Conclusions}

Based on results analysis, when comparison product with and without packaging, bread characteristics in initial phase of storage exhibit allowing only slight changes, with respect weight loss, compared to packed product.. However, in storage time the moisture content and firmness not extended the standard shelf life.

These packaging could be used to keep the product separation by form unitary as primary packaging, for product that would be consumed on same day. Resulting in the decrease of packaging consumption derivate of the petroleum used for same purpose and which has high degradation time. In this context, developing of packaging with potato starch can promote reduction environmental damage.

Another application for such packaging derived from renewable material would be in products which are desirable maintaining the breath, such as some fruits. But, with they were not significant differences between the treatments it is necessary to develop other 
analysis with more days in different environments to better conclude the packing functionality.

\section{References}

[1] Tweed, A.R. A look at French "French Bread". Cereal Fooods world, v.28, n.27, p.397-399, 1983.

[2] Stauffer, C.E. Frozen bakery products. IN: MALLETT, C.P. (ed) . Frozen Food Technology Cambridge: Chapman \& Hall, 1994.

[3] Báguena, R.; Soriano, M. D.; Martinezanaya, M. A; De Barber, C. B. Viability and performance of pure yeast strains in frozen wheat dough., Journal of food science v.56, n.6, p.1690-1694, 1991

[4] Fakhouri, F.M.; Fontes, L. C. B.; Gonçalves, P. V. M.; Milanez, C. R.; Steel, C. J.; Collares-Queiroz, F. P. Filmes e coberturas comestíveis compostas à base de amidos nativos e gelatina na conservação e aceitação sensorial de uvas Crimson. Ciência e Tecnologia de Alimentos, v.27, n.2, p. 369-375, 2007.

[5] Falguera, V.; Quintero, J.P.; Jiménez,A.; Muñoz,J.A.; Ibarz, A. Edible films and coatings: Structures, active functions and trends in their use. Trends in Food Science \& Technology, v. 22, p. 292-303, 2011.

[6] Li, J.M; Nie, S. P. The functional and nutritional aspects of hydrocolloids in foods. Food Hydrocolloids, v. 53, p.46-61, 2016.

[7] Singh, N.; Singh,J.; Kaur, L.; Sodhi, N.S.; Gill, B.S. Morphological, thermal and rheological properties of starches from different botanical sources. Food Chemistry, 81, 219-231, 2003.

[8] Souza, A.C.; Benze, R.; Ferrão, E. S. ; Ditchfield, C.; Coelho, A. C. V. ; Tadini, C. C. Cassava starch biodegradable films: Influence of glycerol and clay nanoparticles content on tensile and barrier properties and glass transition temperature. LWT - Food Science and Technology, v. 46, p. 110-117, 2012.

[9] Ferrari, T. B; Leonel, M.; Sarmento, S. B.S. Características dos rizomas e do amido de araruta (Maranta arundinacea) em diferentes estádios de desenvolvimento da planta. Brazilian Journal of Food Technology, v.8, n.2, p. 93-98, 2005.

[10] Licciardello, F.; Capri, L.; Muratore, G. Influence of packaging on the quality maintenance of industrial bread by comparative shelf life testing. Food Packaging and Shelf Life, 1, 19-24, 2014. 
[11] Pagani, M.; Lucisano, M.; Mariotti, M.; Limbo, S..Influence of packaging material on bread characteristics during ageing Packaging Technology and Science, 19, 295-302, 2006.

[12] Fakhouri, F.M. Bioplásticos flexíveis e biodegradáveis à base de amido e gelatina. Tese (Doutorado em Tecnologia de Alimentos) - Faculdade de Engenharia de Alimentos, Universidade Estadual de Campinas. Campinas, SP, 271 p., 2009.

[13] Licciardello, F.; Giannone, V.; Del Nobile, M. A.; Muratore, G.; Summo, C. Giarnetti ,M.; Caponio, F.; Paradiso, V. M.; Pasqualone, A.. Shelf life assessment of industrial durum wheat bread as a function of packaging system. Food Chemistry, 224, 181-190, 2017.

[14] Licciardello, F.; Cipri, L.; Muratore, G. Influence of packaging on the quality maintenance of industrial bread by comparative shelf life testing. Food Packaging and Shelf Life, 1, (1), 19-24, 2014.

[15] Pagani, M.; Lucisano, M. ;Mariotti, M.; Limbo, S. Influence of packaging material on bread characteristics during ageing. Packaging Technology and Science, 19 (5) (2006), pp. 295-302

[16] Cioban, C.; Milin, A.; Cozma, A.; Aurel, A. Impact of packaging on bread quality and conservation. Lucrări Ştiinţifice, 52, 241-246, 2009. 